\title{
Jolanta Nocoń
}

Uniwersytet Opolski

\section{Diagnozowanie sprawności mówienia w perspektywie (nie tylko) egzaminu maturalnego}

\author{
Diagnosing speaking skills in the perspective (not only) of the matriculation exam
}

\begin{abstract}
The article discusses the difficulties of diagnosing speaking skills in the situation of matriculation examination, resulting from the specific nature of spoken language varieties and texts implementation in these variants. Factors that should be taken into account when formulating criteria for assessing speech and conversation exams are: complex and holistic structure of spoken speech, transience of audible text, the spontaneity of live speech, the power of nonverbal codes, a significant stigma of a dialog, and the influence of situational context on the course of communicative interaction. The analysis of speaking skills assessment tools prepared for the oral examination in the year 2015 revealed that some of them had a significant impact on the criteria developed for this purpose.
\end{abstract}

Keywords: speaking skills, educational diagnosis, assessment criteria, variety of spoken language, examination situation.

\section{Mówienie - sprawność zaniedbana przez szkołę}

Mówienie to jedna z czterech sprawności językowych (obok pisania, czytania i słuchania), wokół których powinno koncentrować się kształcenie językowo-komunikacyjne na lekcjach języka polskiego. W programie obowiązującym przed rokiem 1999 cele i treści kształcenia $\mathrm{w}$ zakresie rozwijania i doskonalenia tej umiejętności zapisano $\mathrm{w}$ dziale „Ćwiczenia w mówieniu i pisaniu”, jednak w powszechnym przekonaniu środowiska nauczycieli-polonistów szkoła miała uczyć przede wszystkim pisania i czytania, natomiast mówienie i słuchanie uznawano za kompetencje nabywane w procesie językowo-komunikacyjnej socjalizacji. Stąd też przez lata nie wypracowano stosownej metodyki, a działania edukacyjne de facto sprowadzane były do aranżowania na lekcjach mówionych interakcji edukacyjnych 
(odpowiadanie na pytania nauczyciela i ustne relacje z wykonania poleceń). Ale taką „edukację” uczeń przechodził także na lekcjach innych przedmiotów i nie mówiło się wówczas o kształceniu umiejętności mówienia ${ }^{1}$. Poza tym dominacja heurezy w procesie kształcenia kulturowo-literackiego powodowała, że liczba uczniów mających szansę zabrać głos ograniczała się do wąskiego grona kilku osób (które i tak z reguły nie miały większych problemów z mówieniem), reszta milczała. Inne działania skoncentrowane na mówieniu (m.in. recytacje, tworzenie ad hoc dłuższych wypowiedzi ustnych) pojawiały się sporadycznie. Doszło do wyraźnej dysproporcji między wagą umiejętności porozumiewania się za pomocą mowy dźwiękowej w pozaszkolnych kontaktach komunikacyjnych (tam mówienie dominuje nad kontaktami „pisanymi”) a usytuowaniem mówienia na peryferiach lekcji języka polskiego.

Dzisiaj powszechne stało się przekonanie, że wielu uczniów z wszystkich etapów edukacji szkolnej ma trudności z mówieniem i że niska kompetencja w zakresie tej sprawności urosła do rangi jednego z najważniejszych problemów edukacyjnych. Sformułowanie dłuższej wypowiedzi na zadany temat stanowi dla znacznej grupy uczniów zadanie prawie niewykonalne, podobnie jak zabranie głosu w dyskusji, tymczasem DOBRE mówienie jest umiejętnością, która warunkuje dalsze ich losy, otwiera szanse na sukces w życiu. Na poprawę zaistniałej sytuacji nie wpłynęło ani dowartościowanie umiejętności mówienia w kolejnych podstawach programowych dla zreformowanej szkoły (poczynając od 1999 roku), ani zmiana formuły części ustnej egzaminu maturalnego (wprowadzenie formy prezentacji ustnej ${ }^{2}$ ). Przyczyn zapewne jest wiele i mają one złożony charakter zagadnienie to nie jest przedmiotem artykułu, ale może należałoby wspomnieć o, ciągle, braku opracowania metodyki mówienia oraz o, ciągle, zbyt małej uwadze poświęcanej na lekcjach języka polskiego doskonaleniu i rozwijaniu sprawności mówienia, może także o niewystarczającym merytorycznym i dydaktycznym przygotowaniu nauczycieli do kształcenia tej sprawności (a to już problem programów studiów polonistycznych nieprzystających do potrzeb edukacji szkolnej). W takim kontekście modernizację ustnego egzaminu maturalnego od 2015 roku należy widzieć jako kolejną próbę nadania kompetencji mówienia należnej jej rangi edukacyjnej. Czy udaną? Czy na lekcjach języka polskiego

\footnotetext{
1 Jak pisze Anna Tabisz, aby mówić o kształceniu sprawności mówienia, proces nauczania-uczenia się musi przyjąć postać swoistego treningu komunikacyjnego: „Zachowania komunikacyjne powinny wcześniej zostać zaplanowane przez nauczyciela i funkcjonować na lekcjach jako zadania dydaktyczne, a ich wykonanie podlegać refleksji i wartościowaniu" (Tabisz 2013, 9).

${ }^{2}$ Wiele prezentacji maturalnych to wypowiadanie tekstu wcześniej zapisanego.
} 
sprawność ta autentycznie będzie kształcona, a kompetencje uczniów wzrosną? $\mathrm{Na}$ odpowiedzi na te pytania trzeba będzie jeszcze poczekać.

\section{Specyfika odmiany mówionej a trudności diagnostyczne}

Formuła egzaminu zewnętrznego jest jednym z czynników najsilniej oddziałujących na przebieg procesu dydaktycznego ${ }^{3}$, stąd niezwykle istotne jest, aby wprowadzane zmiany czy też modernizacje zadań egzaminacyjnych, przed którymi postawiony zostanie uczeń, mądrze wspierały nauczanie-uczenie się. Mam tu na myśli sprawdzanie w sytuacji egzaminacyjnej przede wszystkim kompetencji kluczowych dla danego przedmiotu szkolnego, mających znaczący wpływ na rozwój ucznia i istotnych dla jego dalszych losów. Wtedy jest szansa, że do rozwijania i doskonalenia tych kompetencji z większą uwagą podejdą nie tylko nauczyciele, ale także uczniowie i ich rodzice. $Z$ drugiej jednak strony - co stanowi istotny problem - muszą być to kompetencje sprawdzalne, tzn. poddające się zobiektywizowanej procedurze oceniania, gwarantującej rzetelność i trafność diagnostyczną. To bywa niezwykle trudne w przypadku kompetencji złożonych, a do takich należą wszystkie sprawności komunikacyjne, w tym umiejętność formułowania i wygłoszenia dłuższej wypowiedzi na zadany temat oraz uczestniczenia $\mathrm{w}$ rozmowie wokół tej wypowiedzi - z takim właśnie zadaniem będą mierzyć się maturzyści na egzaminie ustnym z języka polskiego od 2015 roku $^{4}$. To nie jest wyłącznie problem egzaminatorów, ale każdego nauczyciela, który powinien umieć diagnozować kompetencje swoich uczniów nie tylko, by je oceniać, ale przede wszystkim by profilować własny system kształcenia.

To, że kompetencja mówienia bardzo trudno poddaje się procedurze sprawdzania efektów edukacyjnych, wynika przede wszystkim ze specyfiki odmiany mówionej języka i realizowanych w tej odmianie wypowiedzi. Przedstawmy te najważniejsze wraz z kreowanymi przez nie dylematami egzaminacyjnymi:

1. Wypowiadanie się $\mathrm{w}$ mowie dźwiękowej, zarówno monologowe, jak i dialogowe, ma charakter złożony, przy tym holistyczny, globalny. Wprawdzie można wyodrębnić „składowe” mówienia, ale trzeba pamiętać, że w tym przypadku analityczne części nie sumują się do całości, przy tym relacje między nimi są skomplikowane, wieloaspektowe i wykraczają poza prostą kolekcję cech. To powoduje, że każdy tekst mówiony jest inaczej skonfigurowany, niepowtarzalny, jednostkowy i bardzo trudny do wartościującego odniesie-

\footnotetext{
3 Chodzi o tzw. „uczenie pod egzamin”, sprowadzające się z jednej strony do preferowania tych treści kształcenia, które sprawdzane są podczas egzaminu zewnętrznego, z drugiej, do rozwiązywania testów egzaminacyjnych w trakcie lekcji.

${ }^{4}$ Więcej o nowej formule części ustnej egzaminu maturalnego od 2015 roku zob. Nocoń 2013.
} 
nia do podobnych ${ }^{5}$ tekstów innych autorów. W sytuacji egzaminacyjnej konieczne jednak staje się znalezienie płaszczyzny porównania, co oznacza opracowanie wspólnych dla wszystkich tego typu tekstów zasad ich oceniania. Ideałem byłby model holistyczny, ale jak do tej pory, nie udało się go stworzyć ${ }^{6}$. Wszystkie inne, w pewnym sensie zastępcze modele, jak np. wielopoziomowe kryteria czy tzw. analityczne klucze odpowiedzi powstają w drodze arbitralnych wyborów jedynie pewnych aspektów wypowiedzi mówionej czy też pisanej, które mają być oceniane, i siłą rzeczy nie ujmują tekstu uczniowskiego jako niepowtarzalnej całości ze zindywidualizowanymi mocnymi i słabymi stronami.

2. Istotnym utrudnieniem $\mathrm{w}$ procesie oceniania wypowiedzi mówionych (monologowych i dialogowych) jest ulotność tekstu dźwiękowego, który ,ginie sukcesywnie już w trakcie powstawania, bo pod względem fizycznym jest tylko ciągiem krótkotrwałych zjawisk akustycznych” (Nieckula 1993, 103). Ulotność mowy powoduje, że wypowiadany tekst nigdy nie jest odbierany jako całość, tylko jako linearny ciąg wysłuchiwanych w danym momencie fragmentów. Rekonstrukcja całości następuje dopiero w fazie oceniania, co oznacza, że słuchający (nauczyciel, egzaminator) musi „zapamiętać” wypowiedź nadawcy we wszystkich jej wymiarach: treściowym, kompozycyjnym, stylowym, pragmatycznym, a oceniając, może polegać jedynie na własnej pamięci, chyba że wypowiedź zostanie utrwalona w postaci nagrania i będzie można ją w każdej chwili odtworzyć ${ }^{7}$. W sytuacji egzaminacyjnej zapamiętanie wypowiedzi zdającego wspomóc może słuchanie ukierunkowane na określone jej aspekty (opisane na przykład w kryteriach).

3. Kolejna ważna cecha żywej mowy, mająca istotne konsekwencje w procedurze diagnostycznej, to jej spontaniczność. Cecha ta jest stopniowalna: od wypowiedzi tworzonych ad hoc, bez jakiegokolwiek przygotowania, aż do ustnych tekstów reprodukowanych, wcześniej opracowanych treściowo oraz formalnie i odtwarzanych z pamięci przez wypowiadającego się (Ożóg 1993, 94-95). Maturalne wypowiedzi ustne, zarówno prezentacja, jaki wypowiedź retoryczna (od 2015 roku) sytuują się pomiędzy skrajnymi pozycjami spontaniczności $^{8}$ - w obu przypadkach uczniowi umożliwiono wcześniejsze przygotowanie się do wygłoszenia tekstu, choć w różnym wymiarze czasowym: kilka miesięcy jeśli chodzi o prezentację (od zatwierdzenia tematu), do 15 minut w przypadku wypowiedzi retorycznej (od wylosowania tematu). Różnice czasowe nie są bez znaczenia - oddzielenie przygotowania

\footnotetext{
${ }^{5}$ Podobieństwo rozumiem jako teksty na ten sam temat, w tej samej formie gatunkowej i powstałe w tej samej sytuacji komunikacyjnej.

${ }^{6}$ Głównym problemem jest trudna do syntetycznego, opisowego ujęcia wielowariantywność tekstów/ wypowiedzi egzaminacyjnych.

${ }^{7}$ Procedury egzaminacyjne takiej możliwości, jak na razie, nie dopuszczają.

${ }^{8}$ Jedynie rozmowa egzaminacyjna ma charakter w pełni spontaniczny.
} 
prezentacji od momentu jej wygłoszenia umożliwia, przynajmniej teoretycznie, nadanie wypowiedzi ustnej cech odmiany pisanej języka (wcześniejsze napisanie tekstu, wyuczenie na pamięć i odtworzenie w mowie dźwiękowej), gdy tymczasem „doraźność operacji wypowiedzeniotwórczych, konieczność natychmiastowego mówienia powoduje, że w mówionej odmianie polszczyzny ogólnej (także w odmianach regionalnych i gwarach) występują zjawiska nieznane polszczyźnie pisanej” (Ożóg 1993, 94), przede wszystkim na poziomie składni i spójności lokalnej (m.in. potok składniowy, brak logicznych powiązań między zdaniami, różne dewiacje składniowe, w tym przejęzyczenia i anakoluty). Dla mowy dźwiękowej charakterystyczna jest także bieżąca korekta tekstu (poprawianie go w toku mówienia) ${ }^{9}$ i przerwy na namysł nad dalszym jego ciągiem (zob. Tabisz 2014). Wszystkie te cechy ujawniać się będą w wypowiedzi maturalnej od 2015 roku - czas dany na jej przygotowanie spożytkowany zostanie przez zdających zapewne na przemyślenie aspektu treściowego, ewentualnie napisanie krótkiego planu/konspektu (zarys kompozycji), natomiast kształt językowy powstawać będzie ad hoc. To oznacza, że nie można automatycznie przekładać kryteriów oceny aspektu językowo-stylowego z wymagań stawianych wypracowaniom pisemnym na wypowiedzi mówione, bo nie przystają one w pełni do siebie. Istotnym problemem diagnostycznym jest brak, jak dotąd, językoznawczego opracowania normy odmiany mówionej języka polskiego (zob. Podracki 2013), co w efekcie może przekładać się na nadmiernie subiektywne ocenianie poprawności językowo-stylowej uczniowskiego tekstu mówionego.

4. Innym zjawiskiem mającym wpływ na proces diagnozowania jest tzw. teatralność mowy tekst mówiony w swym aspekcie werbalnym jest tylko częścią składową tekstu szerszego (globalnego), który konstytuowany jest także przez inne kody: foniczny z subkodem prozodycznym, kinezyczny (ruchowy) i proksemiczny (przestrzenny) (Ożóg 1993, 94). Komponenty niewerbalne są integralnym składnikiem komunikacji interpersonalnej, współdziałającym $\mathrm{z}$ mową werbalną $\mathrm{i}$ pełniącym istotne funkcje komunikacyjne. Dale G. Leathers wymienia sześć takich funkcji: (1) przekazywanie informacji, (2) regulowanie interakcji, (3) wyrażanie emocji, (4) tworzenie metakomunikacji, (5) kontrolowanie sytuacji społecznych, (6) kształtowanie wrażeń i kierowanie nimi (Leathers 2007, 35). W sytuacji egzaminacyjnej istotne znaczenie zyskują szczególnie dwie funkcje środków niewerbalnych (przede wszystkim fonicznych i prozodycznych), którymi powinien

\footnotetext{
9 „Myśl biegnie bowiem szybciej niż słowo, częściej myślimy o czymś innym, a o czym innym mówimy, zaczynamy pewne zdanie wypowiadać, nie kończymy go, zmieniamy intencję wypowiedzi, dookreślamy, dopowiadamy nowe kwestie, stwierdzamy pomyłkę, nieprecyzyjność wypowiedzi itp.” (Ożóg 1993, 95).
} 
umiejętnie posługiwać się uczeń w wypowiedzi mówionej ${ }^{10}$ : komunikatywna, czyli wspieranie (czasami nawet dodawanie) sensu wyrażonego werbalnie, oraz metatekstowa, tzn. sygnalizowanie rozczłonkowania tekstu na segmenty. Diagnozowanie tego typu kompetencji wymagałoby jednak opanowania przez egzaminatorów umiejętności, które pozwoliłyby na oddzielenie środków niewerbalnych funkcjonalnie użytych przez ucznia w wygłaszanej przez niego wypowiedzi, uzasadnionych i wnoszących merytoryczne wartości do tekstu, od tych, które jedynie budują „dobre wrażenie”, oczarowują płynnością i melodią mowy, zaangażowaniem emocjonalnym, barwą głosu lub, wręcz przeciwnie, nastawiają negatywnie do mówiącego. Subiektywnie oddziaływać na słuchacza mogą m.in. ekspresja twarzy (mimika), zachowania wzrokowe, ruchy ciała (gestykulacja), a także wygląd fizyczny (zob. Leathers 2007).

5. Jeszcze inne trudności diagnostyczne kreuje sytuacja, w jakiej przebiega rozmowa egzaminacyjna. Specyficzna dla komunikacji „twarzą w twarz” silna dialogowość i bezpośrednia interakcyjność powodują, że swój wkład w przebieg interakcji ma nie tylko uczeń, ale mają także egzaminatorzy - to oni inicjują dialog (otwierają pole tematyczne, czyli ustalają, co będzie przedmiotem rozmowy), są jego aktywnymi uczestnikami (m.in. zamykają wątki i otwierają nowe) oraz decydują o zakończeniu interakcji. Mogą także sugerować kierunek rozważań, np. konieczność odniesienia się do stanowiska polemicznego, rozważenie kontrargumentów, rozwinięcie wątku zbyt pobieżnie omówionego w wypowiedzi itp. Popełniane przez egzaminatorów błędy w reżyserowaniu rozmowy egzaminacyjnej (np. zbyt szczegółowe repliki inicjujące, niewymagające udzielenia dłuższej odpowiedzi) mogą mieć negatywny wpływ na przebieg tej części egzaminu, tym samym problemem staje się nie tylko oddzielenie „wkładu” komisji od „wkładu” zdającego maturę ustną, ale również oszacowanie wpływu egzaminatorów na jakość wypowiedzi ucznia. Kolejna trudność z diagnozowaniem umiejętności uczestniczenia $\mathrm{w}$ rozmowie wiąże się z kontekstem sytuacyjnym, w jakim egzamin ustny przebiega. Dla tego typu interakcji właściwa jest odmiana konwersacyjna języka mówionego, charakteryzująca się m.in. redukcją treści danych sytuacyjnie, niskim poziomem strukturyzacji składni oraz szerokim zastosowaniem elipsy (Ożóg 1993, 95-96). Te właściwości mogą pozostawać w sprzeczności z oczekiwaniami egzaminatorów, w tym mówienia „pełnym/całym zdaniem”, starannej budowy zdań, wysokiej międzyzdaniowej spójności logiczno-gramatycznej. Można się zastanawiać, jakie jest uzasadnienie dla tak wysokich wymagań wobec formy językowej uczniowskich wypowiedzi dialogowych

\footnotetext{
${ }^{10}$ Tym bardziej, że w podstawie programowej z 2008 roku uwzględnione zostały takie umiejętności, jak m.in.: stosowanie odpowiedniej intonacji, wprowadzanie pauzy, przekazywanie głosem intencji tekstu.
} 
(zapewne padnie argument, że ma to świadczyć o wysokiej sprawności językowej zdającego). Wydaje się jednak, że to raczej rozmowa zanurzona w sytuacyjności aktu mowy, w którym przebiega, oczywiście przy zachowaniu adekwatności do sytuacji oficjalnej egzaminu, jest bardziej naturalna i przy tym przyjazna dla ucznia, sprzyja bowiem rozbudzeniu tzw. mowności, a to z kolei może się pozytywnie przełożyć na jakość merytoryczną ocenianych wypowiedzi.

\section{Wypowiedź monologowa i uczestniczenie w rozmowie - kryteria oceniania}

Oczekiwania wobec tekstów mówionych wypowiadanych przez ucznia (monologowych i dialogowych), które mogłyby się stać kryteriami oceniania na egzaminie maturalnym, muszą być powiązane z wymaganiami szczegółowymi wpisanymi w podstawę programową języka polskiego na wszystkich etapach szkolnej edukacji polonistycznej ${ }^{11}$. Spróbujmy w tym miejscu odtworzyć (skrótowo, syntetycznie) ${ }^{12}$ z tych zapisów to, czego oczekuje się od wypowiedzi mówionej (monologowej i dialogowej) ucznia kończącego edukację na poziomie egzaminu maturalnego, by następnie odnieść je do kryteriów oceniania, które będą obowiązywały podczas ustnej części matury od bieżącego roku szkolnego.

Jeśli chodzi o wypowiedź monologową, to - zgodnie z podstawą programową języka polskiego - uczeń powinien umieć: (1) przed wygłoszeniem zaplanować ją i przemyśleć, w tym: zanalizować temat, wybrać formę gatunkową, uporządkować segmenty tekstu zgodnie z funkcjonalnie dobranym porządkiem kompozycyjnym, sporządzić plan swojej wypowiedzi, dobrać słownictwo adekwatne do tematu oraz styl języka do gatunku, (2) wypowiedzieć się na zadany temat, (3) skonstruować wypowiedź zgodnie z podstawowymi regułami organizacji tekstu, szczególnie w zakresie spójności znaczeniowej i logicznej na poziomie globalnym i lokalnym (międzyzdaniowym), (4) wykorzystać zasady logiki i retoryki do skonstruowania wypowiedzi o charakterze argumentacyjnym, (5) publicznie wygłosić monolog z wykorzystaniem środków niewerbalnych, m.in. zadbać o wyrazistość przekazu, dostosować tempo mowy do sytuacji, wspomóc swoją wypowiedź mimiką, gestykulacją i postawą ciała, (6) sprawnie i poprawnie posłużyć się odmianą oficjalną polszczyzny. $Z$ kolei w odniesieniu do wypowiedzi dialogowej oczekuje się, że uczeń, uczestnicząc w rozmowie: (1) będzie mówił na temat, (2) zaprezentuje i uzasadni własne zdanie w dyskutowanej sprawie, (3) odniesie się do poglądów innych, akceptując je lub polemizując z nimi, (4) będzie przestrze-

\footnotetext{
11 Zgodnie $\mathrm{z}$ zasadą kumulatywności sprawności wpisane $\mathrm{w}$ podstawę programową na niższym etapie edukacyjnym powinny być doskonalone i rozwijane na kolejnych etapach.

12 Zob. pełne analityczne zestawienie zapisów w podstawie programowej języka polskiego w zakresie sprawności mówienia od I do IV etapu (Tabisz 2013).
} 
gał zasad etyki mowy w różnych sytuacjach komunikacyjnych, (5) dostosuje się do wymogów etykiety językowej, (6) wesprze swoją wypowiedź środkami niewerbalnymi, przede wszystkim mimiką, gestem, postawą ciała, (7) w zależności od sytuacji posłuży się odmianą oficjalną lub nieoficjalną języka polskiego ${ }^{13}$.

Przejdźmy do kryteriów egzaminacyjnych. Oczywiste jest, że muszą one przystawać do wymagań wpisanych $\mathrm{w}$ podstawę programową, sprawdzać można bowiem tylko to, czego uczy się na lekcjach (powinno się uczyć). Ale nie mogą też nie uwzględniać specyfiki odmiany mówionej języka oraz charakteru samej interakcji komunikacyjnej. Najistotniejsza trudność, z którą trzeba się zmierzyć, ustalając zasady oceniania wypowiedzi monologowej i dialogowej, to wspomniana w drugiej części artykułu złożona struktura tekstu mówionego. W przypadku egzaminu od 2015 roku zdecydowano się na wydzielenie z holistycznej całości pewnych jej aspektów, a następnie przypisanie każdemu z nich kryteriów wskazujących na te elementy wykonania zadania egzaminacyjnego, które podlegają ocenie (wraz ze skalą punktową). Jeśli chodzi o wypowiedź monologową, są to:

a. TREŚĆ - (1) zgodność wypowiedzi z poleceniem (czy jest w całości na temat), (2) stopień realizacji polecenia (czy uwzględniono wszystkie elementy polecenia), (3) jakość realizacji polecenia (czy realizacja została pogłębiona), (4) poprawność rzeczowa i terminologiczna.

b. STRUKTURA - (1) retoryczna organizacja wypowiedzi na poziomie globalnym, (2) spójność wypowiedzi na poziomie lokalnym.

c. STYL I JĘZYK ${ }^{14}$ - (1) stosowność stylu, (2) poprawność gramatyczna i leksykalna, (3) poprawność wymowy i prozodia.

W przypadku rozmowy egzaminacyjnej, oprócz STYLU I JEZZYKA, oceniane są:

a. TREŚĆ - (1) adekwatność wypowiedzi do zagadnienia, (2) stopień rozwinięcia wypowiedzi.

b. PRZESTRZEGANIE ZASAD UCZESTNICZENIA W ROZMOWIE (przede wszystkim zasada uprzejmości i grzeczności językowej).

Kolejność kryteriów w obrębie aspektów nie jest przypadkowa - zostały one zhierarchizowane i przekładają się na liczbę punktów. Największą wagę mają kryteria wymienione

\footnotetext{
${ }^{13}$ Warto zaznaczyć, że wymagania wobec sprawności uczestniczenia w rozmowie zapisane zostały w podstawie programowej języka polskiego dla II, a przede wszystkim dla III etapu edukacyjnego. Na poziomie szkoły ponadgimnazjalnej nie wspomina się o nich.

${ }^{14}$ Styl i język wypowiedzi monologowej i rozmowy egzaminacyjnej będą oceniane łącznie, stąd tylko jedna skala dla obu części egzaminu ustnego.
} 
w kolejnych aspektach jako pierwsze - niska ocena pod tym względem skutkuje utratą największej liczby punktów. Sposób uporządkowania kryteriów ma charakter arbitralnej decyzji, której uzasadnienia można szukać m.in. w celach egzaminu - gdyby za nadrzędny cel uznano sprawdzenie wiedzy, wówczas największe przełożenie na wynik miałaby poprawność rzeczowa i terminologiczna. Zdecydowano jednak inaczej. Pomijam dyskusję, czy można było w inny sposób (lepszy?) skonstruować zasady oceniania obu egzaminacyjnych wypowiedzi ustnych, bo zapewne można było. Obecnie pozostaje sprawdzić je w działaniu, zastrzegając przy tym, że ich diagnostyczna funkcjonalność nie zależy jedynie od wyboru i uporządkowania kryteriów, ale, chyba w znacznie większej mierze, od przygotowania egzaminatorów do posłużenia się danym im narzędziem.

Należałoby natomiast zastanowić się, czy przyjęte kryteria egzaminacyjne nie zatracają specyfiki ustnych interakcji komunikacyjnych i mówionej odmiany języka, czy poradzą sobie z diagnostycznymi komplikacjami opisanymi w części drugiej artykułu. Kryteria te rozkładają złożoną, holistyczną całość na części, diagnozie podlegają tym samym tylko niektóre aspekty sprawności mówienia. To niedoskonałość narzędzia, ale paradoksalnie może ona sprzyjać radzeniu sobie z ulotnością tekstu dźwiękowego, w sytuacji, gdy - jak już wspomniano - nie zdecydowano się na nagrywanie egzaminu ustnego. Precyzyjne, jasne i tym samym łatwe do zapamiętania kryteria mają szansę wspomóc pamięć krótkotrwałą egzaminatorów, kierując ich uwagę na określone elementy wypowiedzi. Tym samym egzaminacyjne słuchanie będzie mogło mieć charakter wybiórczy, a nie globalny. W kryteriach opracowanych na potrzeby nowego egzaminu ustnego uwzględniono także wpływ spontaniczności na styl i język wypowiedzi egzaminacyjnej, uznając, że nie należy oczekiwać od ucznia użycia odmiany pisanej języka. Dlatego też osłabiono wymagania normatywne, dopuszczono składnię typową dla mówienia, przyjęto, że nie będzie się uznawać za błąd braku płynności mowy spowodowanego m.in. przerwami na namysł, zawahaniami oraz autokorektą, dopuszczono elipsę, informacyjną redundancję i powtórzenia językowe. Najsłabsze odniesienie w kryteriach egzaminu ustnego znalazła niewątpliwie teatralność mowy. Właściwie pominięto ten aspekt z wyjątkiem poprawności prozodycznej.

\section{Nauczyć się słuchać}

Na koniec należałoby zwrócić uwagę na pewne potencjalne zagrożenia mogące zakłócić, a nawet zafałszować diagnozę sprawności mówienia. Wszystkie one wiążą się z postawą egzaminatora i kierowaniem się przez niego subiektywnymi oczekiwaniami wobec wypowiedzi ucznia. Przede wszystkim trzeba nauczyć się słuchać, co mówiący ma do powiedzenia 
i jak o tym mówi, a nie porównywać jego wypowiedź z tym, co samemu by się na ten temat powiedziało. Takie nastawienie spowoduje, że kryteria zastępowane będą subiektywnym kluczem odpowiedzi i z góry ustaloną treścią. Ten sam temat może być zrealizowany na różne sposoby - zdający ma do tego prawo, a rolą egzaminatora jest ocenić, na ile dana wypowiedź spełnia wszystkie kryteria egzaminacyjne.

Czasami ujawniać się może tendencja do subiektywnego hierarchizowania wagi poszczególnych kryteriów. Najczęściej na plan pierwszy wysuwany jest aspekt treściowy (w tym przede wszystkim poprawność merytoryczna) oraz poprawność językowa, na dalszy plan schodzą natomiast pozostałe kryteria. To może powodować przecenianie lub niedocenianie wartości wypowiedzi w zależności od tego, gdzie usytuowane są jej słabe strony.

Podobny skutek przynieść może, o czym była mowa wcześniej, słaba odporność egzaminatora na wrażenia słuchowe, czasami przesłaniające pozostałe aspekty wypowiedzi. Łatwość i płynność mowy, umiejętne posługiwanie się środkami niewerbalnymi sprzyja stwarzaniu pozytywnego wrażenia. W efekcie zamiast słuchać, co uczeń mówi, egzaminator poddaje się czarowi sposobu, w jaki mówi. Także niepozytywne wrażenia słuchowe odwracają uwagę od meritum wypowiedzi.

Ostatnie zagrożenie wiąże się z nadmiernymi oczekiwaniami wobec stylu i języka wypowiedzi mówionej. Sytuację komplikują nieprecyzyjne normy ilościowo-jakościwe typu: w petni - częściowo - wcale, liczne - nieliczne, rażace - nierażace, jakimi posłużono się w opisie norm zaliczenia poszczególnych kryteriów. Przede wszystkim należy pamiętać, by podczas diagnozowania sprawności mówienia nie zatracić istoty żywej mowy i nie żądać od ucznia, że będzie mówił tak, jak pisze.

\section{Bibliografia}

Leathers Dale G., 2007, Komunikacja niewerbalna, przeł. Trzcińska M., Warszawa.

Nieckula Franciszek, 1993, Język ustny a język pisany, w: Bartmiński J. (red.), Współczesny język polski, Wrocław, s. 101-114.

Nocoń Jolanta, 2013, Zamiast prezentacji, „Polonistyka”, nr 10.

Ożóg Kazimierz, 1993, Ustna odmiana języka ogólnego, w: Bartmiński J. (red.), Współczesny język polski, Wrocław, s. 87-100.

Tabisz Anna, 2013, Od protojęzyka do sprawności mówienia, „Polonistyka”, nr 10.

Tabisz Anna, 2014, Autokorekta wypowiedzi mówionej jako wyraz świadomości językowej, w: Nocoń J., Tabisz A. (red.), Język a Edukacja 3. Świadomość językowa, Opole, s. $131-139$. 
Jolanta Nocoń - prof. UO dr hab., pracuje w Zakładzie Polonistyki Stosowanej Uniwersytetu Opolskiego. Językoznawca i lingwodydaktyk. Autorka książek Polecenia i pytania w podręcznikach do nauki o języku (1997) Podręcznik szkolny w dyskursie dydaktycznym - tradycja i zmiana (2009) oraz artykułów z zakresu dydaktyki języka polskiego, stylistyki lingwistycznej i analizy dyskursu. Współredaktorka serii wydawniczej „Język a Edukacja”, współautorka Stylów współczesnej polszczyzny. Przewodnika po stylistyce polskiej (2013) i przewodnika dla rzeczoznawców MEN oceniających podręcznik szkolny w aspekcie językowym. Członek Zespołu Dydaktycznego Rady Języka Polskiego przy Polskiej Akademii Nauk. Współpracuje z IBE oraz z CKE. 